\title{
GARNETS FROM MADAGASCAR WiTH A COLOR CHANGE OF BLUE-GREEN TO PURPLE
}

\author{
By Karl Schmetzer and Heinz-Jürgen Bernhardt
}

\begin{abstract}
Gemological, chemical, spectroscopic, and microscopic properties of bluegreen color-change garnets from a new deposit near Bekily, Madagascar, are given. The samples are members of the pyrope-spessartine solid-solution series, with smaller constituents of almandine and grossular. The alexandrite-like color change from blue-green in daylight to purple in incandescent light is mainly caused by relatively high amounts of vanadium (about $\mathrm{I} \mathrm{wt} . \% \mathrm{~V}_{2} \mathrm{O}_{3}$ ). These garnets are particularly noteworthy because they represent the first commercially available "blue" garnets.
\end{abstract}

\begin{abstract}
Although gem-quality color-change garnets have been known from Sri Lanka and Tanzania, interest in this phenomenal material has grown rapidly with the discovery of new deposits near Tunduru (Tanzania) and especially Madagascar. In particular, the discovery in Madagascar of commercial quantities of color-change garnets that are greenish blue to blue-green in daylight represents the first "blue" garnets to enter the gem market (figure 1). Although cut
\end{abstract}

\section{ABOUT THE AUTHORS}

Dr. Schmetzer is a research scientist residing in Petershausen, near Munich, Germany. Dr. Bernhardt is a research scientist at the Institute of Mineralogy of Ruhr University, Bochum, Germany.

Acknowledgments: The authors are grateful to Professor Dr. H. A. Hänni, of the SSEF Swiss Gemmological Institute in Basel, for performing Raman analysis of the inclusions.

Gems \& Gemology, Vol. 35, No. 4, pp. 196-201

(c) 1999 Gemological Institute of America stones are usually small $(0.1-0.8 \mathrm{ct})$, many stones over $1 \mathrm{ct}$ have been reported. The largest faceted topquality blue-green color-change garnet seen to date is $9.5 \mathrm{ct}$ (T. Hainschwang, pers. comm., 1999).

In general, garnets that show a distinct color change from green to bluish green in day (or fluorescent) light and red to reddish purple in incandescent light are subdivided into two groups according to their chemical composition. The first group consists of chromium-rich pyropes with chromium contents above 3 wt. $\% \mathrm{Cr}_{2} \mathrm{O}_{3}$. Chemical properties of samples from this first group have been reviewed by Schmetzer et al. (1980), but faceted gem material has been seen only rarely in the trade. Occasionally, garnet inclusions in diamond (see Fryer, 1982) reveal this chemical composition.

The second group of color-change garnets is more commonly seen as faceted gem material. This group is formed by members of the pyrope-spessartine solid-solution series that also contain minor molecular percentages of almandine and grossular. The color change in these garnets always is associated with small amounts of $\mathrm{V}_{2} \mathrm{O}_{3}$ and/or $\mathrm{Cr}_{2} \mathrm{O}_{3}$ (Schmetzer and Ottemann, 1979; Schmetzer et al., 1980; Stockton, 

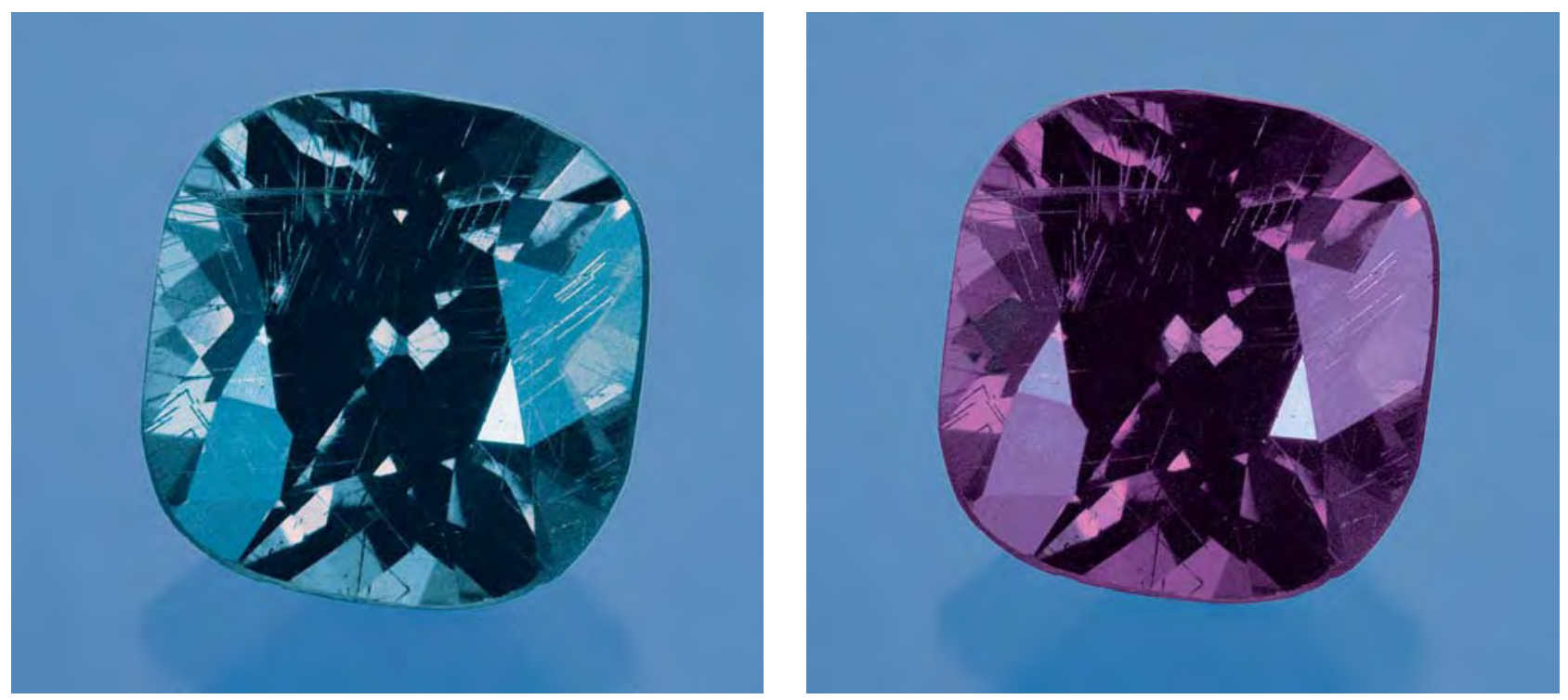

Figure 1. This $1.00 \mathrm{ct}$ color-change garnet is from a new source near Bekily, Madagascar. The vanadium-rich pyrope-spessartine garnet is blue-green in day or fluorescent light (left) and purple in incandescent light (right). Photo by Maha Tannous.

1982; Gübelin and Schmetzer, 1982; Manson and Stockton, 1984; and Stockton and Manson, 1985; for a recent colorimetric study of various color-change gem materials, see Liu et al., 1999). Historically, most samples of this second type of color-change garnet have originated from different localities in only two countries: Embilipitiya and Athiliwewa, in Sri Lanka; or Umba and Tunduru, in Tanzania (see references given above as well as Koivula and Kammerling, 1988; Johnson and Koivula, 1996a and b, 1998a).

In 1998, the first color-change pyrope-spessartine garnets from Madagascar were mentioned (Johnson and Koivula, 1998b). These samples were greenish yellow in daylight and intense pink to red in incandescent light. Recently, a second variety of color-change pyrope-spessartine from Madagascar was made available to one of the authors (KS). The color of this material varies from bluish green to greenish blue (almost pure blue) in daylight, with a distinct color change to intense purple in incandescent light (figure 1). The present study was undertaken to characterize this new material, the daylight color of which is very unusual compared to that of other garnets, both single color and color change, that have entered the marketplace thus far (see again Johnson and Koivula, 1996a and b). For convenience, the color-change garnets discussed in this article will be referred to hereafter as "bluegreen," their predominant daylight color.

\section{MATERIALS AND METHODS}

For the present study, about 60 faceted blue-green garnets ranging from 0.1 to $2 \mathrm{ct}$ were available. We also examined more than 100 rough samples up to 5 ct. All samples were said to originate from a recently discovered mine near the town of Bekily in southern Madagascar (T. Cushman, J. Henn, H. Hogemann, E. Petsch, and M. Sevdermish, all pers. comm., 1999).

For comparison, we also studied two greenish yellow/pink color-change garnets (1.95 and $0.44 \mathrm{ct}$ ) that had recently come from Madagascar. As was the case for the three garnets of similar color change described in Johnson and Koivula (1998b), these two new samples were purchased at a local gem market in Madagascar, so the exact locality for this material is still unknown. However, these samples probably also originate from the Bekily area (T. Hainschwang and M. Sevdermish, pers. comm., 1999).

We tested more than 20 of the larger faceted blue-green samples and the two greenish yellow ones by standard gemological methods for refractive index, fluorescence to long- and short-wave ultraviolet radiation, and density. We examined all of the available samples (both rough and cut) for inclusions and internal structure by standard microscopic techniques using different microscopes and lighting conditions both with and without immersion in methylene iodide.

Chemical properties were determined for eight 
blue-green samples (designated $\mathrm{A}$ to $\mathrm{H}$ ) that represented the full range of refractive indices and densities measured. In addition, we also analyzed the smaller $(0.44 \mathrm{ct})$ greenish yellow sample (designated $\mathrm{X}$. For quantitative chemical analyses of all nine faceted samples, a Cameca Camebax SX 50 electron microprobe was used, with traverses of 15 point analyses across the table of each sample.

For 30 rough and faceted (approximately half each) blue-green garnets and for the two greenish yellow stones, we recorded spectroscopic data with a Leitz-Unicam SP 800 spectrophotometer for the visible-to-UV range.

To identify the needle-like inclusions observed in the blue-green garnets, we used the electron microprobe described above. For this examination, we analyzed several faceted stones in which the needles reached the surface, as well as a few samples of rough material on which we had faces specially polished. Inclusions in three of these rough samples were also analyzed by laser Raman microspectrometry using the Renishaw system.

TABLE 1. Physical and chemical properties of color-change garnets from Madagascar.

\begin{tabular}{|c|c|c|c|c|c|c|c|c|c|}
\hline \multirow[t]{2}{*}{$\begin{array}{l}\text { Physical and chemical } \\
\text { properties }\end{array}$} & \multicolumn{8}{|c|}{$\begin{array}{l}\text { Blue-green (daylight) /purple (incandescent light) } \\
\text { samples }\end{array}$} & \multirow{2}{*}{$\begin{array}{c}\begin{array}{c}\text { Greenish } \\
\text { yellow/pink } \\
\text { sample }\end{array} \\
\mathrm{X}\end{array}$} \\
\hline & A & B & C & $\mathrm{D}$ & $E$ & $\mathrm{~F}$ & G & $\mathrm{H}$ & \\
\hline Refractive index & 1.759 & 1.760 & 1.760 & 1.761 & 1.763 & 1.765 & 1.766 & 1.767 & 1.764 \\
\hline Density $\left(\mathrm{g} / \mathrm{cm}^{3}\right)$ & 3.87 & 3.87 & 3.88 & 3.89 & 3.90 & 3.92 & 3.92 & 3.93 & 3.91 \\
\hline \multicolumn{10}{|l|}{ Microprobe analyses (wt.\%) ${ }^{\mathrm{a}}$} \\
\hline $\mathrm{MgO}$ & 14.02 & 13.23 & 13.03 & 12.91 & 11.58 & 11.66 & 11.42 & 11.53 & 10.02 \\
\hline $\mathrm{CaO}$ & 2.09 & 2.46 & 2.27 & 2.28 & 2.13 & 2.39 & 2.71 & 2.21 & 4.21 \\
\hline $\mathrm{MnO}$ & 17.22 & 18.02 & 18.02 & 18.33 & 20.17 & 20.09 & 20.58 & 20.61 & 22.07 \\
\hline $\mathrm{FeO}^{\mathrm{b}}$ & 3.44 & 2.55 & 3.14 & 3.44 & 3.19 & 3.10 & 2.86 & 3.14 & 1.80 \\
\hline $\mathrm{V}_{2} \mathrm{O}_{3}$ & 0.95 & 0.98 & 1.25 & 1.22 & 0.89 & 1.21 & 1.16 & 1.22 & 0.21 \\
\hline $\mathrm{Cr}_{2} \mathrm{O}_{3}$ & 0.15 & 0.23 & 0.25 & 0.24 & 0.14 & 0.24 & 0.36 & 0.20 & 0.18 \\
\hline $\mathrm{Al}_{2} \mathrm{O}_{3}$ & 22.88 & 21.96 & 21.81 & 22.28 & 21.95 & 21.78 & 21.87 & 22.00 & 22.27 \\
\hline $\mathrm{SiO}_{2}$ & 40.64 & 39.24 & 39.34 & 40.05 & 38.96 & 39.12 & 39.61 & 39.38 & 39.43 \\
\hline $\mathrm{TiO}_{2}$ & 0.06 & 0.06 & 0.06 & 0.06 & 0.05 & 0.07 & 0.05 & 0.07 & 0.09 \\
\hline Total & 101.45 & 98.74 & 99.19 & 100.81 & 99.08 & 99.64 & 100.63 & 100.36 & 100.27 \\
\hline \multicolumn{10}{|l|}{ Cations $^{c}$} \\
\hline $\mathrm{Mg}$ & 1.532 & 1.492 & 1.468 & 1.431 & 1.317 & 1.319 & 1.281 & 1.296 & 1.131 \\
\hline $\mathrm{Ca}$ & 0.165 & 0.200 & 0.184 & 0.181 & 0.174 & 0.194 & 0.218 & 0.179 & 0.342 \\
\hline $\mathrm{Mn}$ & 1.069 & 1.155 & 1.153 & 1.155 & 1.303 & 1.291 & 1.312 & 1.317 & 1.416 \\
\hline $\mathrm{Fe}$ & 0.211 & 0.161 & 0.198 & 0.214 & 0.204 & 0.197 & 0.180 & 0.198 & 0.114 \\
\hline V & 0.056 & 0.060 & 0.076 & 0.073 & 0.054 & 0.074 & 0.070 & 0.074 & 0.013 \\
\hline $\mathrm{Cr}$ & 0.009 & 0.014 & 0.015 & 0.014 & 0.009 & 0.014 & 0.021 & 0.012 & 0.011 \\
\hline $\mathrm{Al}$ & 1.977 & 1.958 & 1.942 & 1.953 & 1.974 & 1.949 & 1.939 & 1.956 & 1.988 \\
\hline $\mathrm{Si}$ & 2.979 & 2.970 & 2.972 & 2.978 & 2.972 & 2.970 & 2.980 & 2.971 & 2.986 \\
\hline $\mathrm{Ti}$ & 0.003 & 0.004 & 0.003 & 0.003 & 0.003 & 0.004 & 0.003 & 0.004 & 0.005 \\
\hline \multicolumn{10}{|l|}{ Mol.\% end-members ${ }^{d}$} \\
\hline Pyrope $\left(\mathrm{Mg}_{3} \mathrm{Al}_{2} \mathrm{Si}_{3} \mathrm{O}_{12}\right)$ & 51.46 & 49.61 & 48.88 & 47.99 & 43.93 & 43.95 & 42.83 & 43.34 & 37.67 \\
\hline Grossular $\left(\mathrm{Ca}_{3} \mathrm{Al}_{2} \mathrm{Si}_{3} \mathrm{O}_{12}\right)$ & 2.37 & 3.06 & 1.64 & 1.84 & 2.72 & 2.16 & 2.80 & 1.77 & 10.21 \\
\hline Spessartine $\left(\mathrm{Mn}_{3} \mathrm{Al}_{2} \mathrm{Si}_{3} \mathrm{O}_{12}\right)$ & 35.93 & 38.40 & 38.40 & 38.74 & 43.47 & 43.03 & 43.85 & 44.05 & 47.16 \\
\hline Almandine $\left(\mathrm{Fe}_{3}^{2+} \mathrm{Al}_{2} \mathrm{Si}_{3} \mathrm{O}_{12}\right)$ & 7.08 & 5.36 & 6.60 & 7.18 & 6.79 & 6.55 & 6.02 & 6.64 & 3.79 \\
\hline Goldmanite $\left(\mathrm{Ca}_{3} \mathrm{~V}_{2}^{3+} \mathrm{Si}_{3} \mathrm{O}_{12}\right)$ & 2.72 & 2.93 & 3.73 & 3.56 & 2.67 & 3.61 & 3.46 & 3.62 & 0.64 \\
\hline Uvarovite $\left(\mathrm{Ca}_{3} \mathrm{Cr}_{2} \mathrm{Si}_{3} \mathrm{O}_{12}\right)$ & 0.44 & 0.64 & 0.75 & 0.69 & 0.42 & 0.70 & 1.04 & 0.58 & 0.53 \\
\hline
\end{tabular}




\section{RESULTS FOR THE BLUE-GREEN COLOR-CHANGE GARNETS}

Visual Appearance and Gemological Properties. All the rough samples were irregular fragments of originally larger crystals. No external crystal faces were observed.

All samples, faceted and rough, revealed a homogenous bluish green, blue-green, or greenish blue color in daylight, with a distinct change to purple in incandescent light (again, see figure 1). The color of this new material under both lighting conditions is close to that seen in the natural alexandrite from Russia's Ural Mountains that is currently available in the trade. The variation in color from one sample to another was small. Refractive indices were found to vary within a small range, from 1.759 to 1.767 . The densities ranged from 3.87 to 3.93 $\mathrm{g} / \mathrm{cm}^{3}$ (table 1). All the blue-green garnets were inert to both long- and short-wave UV radiation.

Chemical Properties. All eight blue-green garnets analyzed were relatively homogeneous in composition, without any distinct chemical zoning. All were members of the pyrope-spessartine solid-solution series, with pyrope contents from 43 to $51 \mathrm{~mol}$.\% and spessartine contents from 36 to 44 mol.\% (table 1). All also contained minor percentages of almandine and grossular. In addition, these blue-green color-change samples revealed unusually high amounts of vanadium $\left(0.89-1.25 \mathrm{wt} . \% \mathrm{~V}_{2} \mathrm{O}_{3}\right)$ and distinctly smaller percentages of $\mathrm{Cr}_{2} \mathrm{O}_{3}(0.14-0.36 \mathrm{wt} . \%$; see table 1).

Spectroscopic Properties. The absorption spectrum of the blue-green samples consists of one strong, broad absorption band with a maximum at $571 \mathrm{~nm}$, and a second strong band in the blue-to-violet range with three distinct maxima at 408, 422, and $429 \mathrm{~nm}$ (figure 2). Between these two major absorption bands, we always observed four somewhat weaker maxima at $459,483,503$, and $518 \mathrm{~nm}$.

This type of spectrum is consistent with the data reported in the literature for vanadium-bearing pyrope-spessartines (see, e.g., Schmetzer and Ottemann, 1979; Schmetzer et al., 1980); the absorption bands were assigned to $\mathrm{V}^{3+}(571 \mathrm{~nm})$, $\mathrm{Mn}^{2+}(408,422$, and $483 \mathrm{~nm}), \mathrm{Fe}^{3+}(429 \mathrm{~nm})$, and $\mathrm{Fe}^{2+}$ $(459,503$, and $518 \mathrm{~nm})$. The absorption bands of $\mathrm{Cr}^{3+}$ in garnets occur at positions (about $570 \mathrm{~nm}$ ) almost identical to those of vanadium and, thus, the two superimposed absorptions cannot be separated. Because of the high intensity of the $\mathrm{V}^{3+}\left(\right.$ plus $\left.\mathrm{Cr}^{3+}\right)$

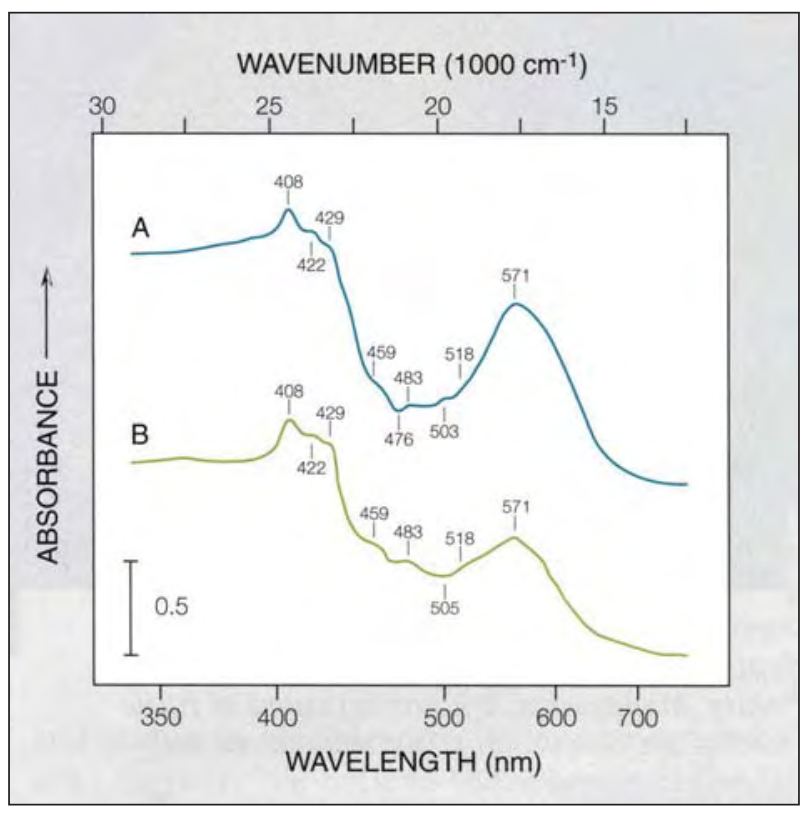

Figure 2. These visible-range absorption spectra are representative of two types of vanadium-rich and chromium-bearing color-change garnets from Madagascar: (A) blue-green and (B) greenish yellow. Absorption maxima were assigned to $\mathrm{V}^{3+}$ (plus $\mathrm{Cr}^{3+}$ ), $\mathrm{Mn}^{2+}, \mathrm{Fe}^{3+}$, and $\mathrm{Fe}^{2+}$; absorption minima (which are responsible for the different colors in day and incandescent light) are found in the blue-green (around $476 \mathrm{~nm}$ ) and green (around $505 \mathrm{~nm}$ ) areas of the visible range, respectively.

absorption band in the yellow region, an absorption minimum always is found in the blue-green range, at about 474 to $476 \mathrm{~nm}$.

Properties Observed with the Microscope. When examined with crossed polarizers, all samples revealed strong anomalous double refraction (figure 3 ); growth patterns were rare. In most of the bluegreen garnets, needle-like inclusions were present in four orientations (again, see figure 3). The angle between any two sets of these inclusions always measured $70^{\circ}$. With one set parallel to the direction of view in the microscope, we always saw a network of the three remaining sets of needles (figure 4), but the axes of these other needles were never oriented perpendicular to the plane of view. From these observations, it is evident that the needles were oriented parallel to the four [111] axes of the garnet.

Electron microprobe analysis of the needlelike inclusions in some of the blue-green garnets 


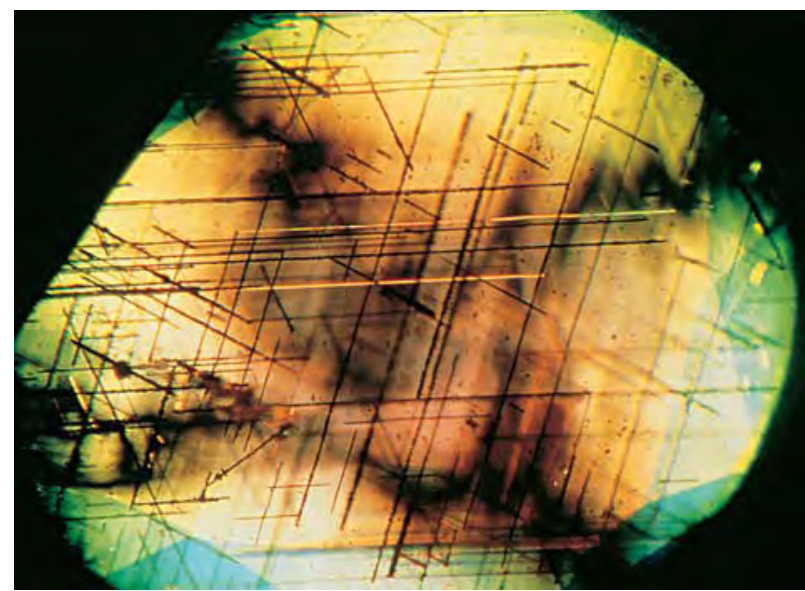

Figure 3. Anomalous double refraction is evident in this blue-green color-change garnet from Bekily, Madagascar. Four orientations of rutile needles are also present. Immersion, crossed polarizers, magnified $30 x$.

revealed that they were rutile, which was confirmed by Raman analysis. The diameter of these rutile needles was in the range of $3 \mu \mathrm{m}$.

In a few samples, we also saw small, rounded mineral inclusions. However, these have not yet been identified.

\section{DISCUSSION}

Comparison with the Greenish Yellow ColorChange Garnets. As also is evident in table 1, the densities and refractive indices of the two greenish yellow samples from Madagascar were within the ranges of density and R.I. for the blue-green samples. Chemical analysis, however, revealed that the greenish yellow sample contained somewhat less pyrope and almandine, and more spessartine, with distinctly more grossular. The microprobe analyses also revealed a chromium content in the same range as for the blue-green material, but there was distinctly less vanadium in the greenish yellow sample. The most prominent internal features were dense groups of small, thin "needles" in different orientations.

The lower percentages of $\mathrm{V}_{2} \mathrm{O}_{3}$ and $\mathrm{FeO}$ in the greenish yellow garnet result in the day- and incandescent-light colors that differ from those of the blue-green material (figure 5). Although absorption bands of $\mathrm{V}^{3+}, \mathrm{Cr}^{3+}, \mathrm{Mn}^{2+}, \mathrm{Fe}^{3+}$, and $\mathrm{Fe}^{2+}$ in the spectrum (again, see figure 2) of the greenish yellow garnet resemble those of the blue-green garnets, the former has an absorption minimum in the green range near $505 \mathrm{~nm}$. Also contributing to the different colors of the greenish yellow material are the lower intensity of the vanadium-chromium band in the yellow range and of the iron bands in the green region.

Comparison with Other Vanadium-Bearing Garnets. Subsequent to the description of a vanadium-bearing green gem grossular from southern Madagascar (Mercier et al., 1997), we now have examined two types of vanadium-bearing garnets from this island nation, in this case color-change members of the pyrope-spessartine solid-solution series. The chemical properties and colors of the greenish yellow sample were similar to color-change garnets from Sri Lanka and Tanzania that have been known for about 20 years (Schmetzer and Ottemann, 1979; Schmetzer et al., 1980; Stockton, 1982; Gübelin and Schmetzer, 1982; Manson and Stockton, 1984; Stockton and Manson, 1985).

The unusual blue-green color of the new colorchange garnets from Bekily is due mainly to an extremely high vanadium content. A similar high amount of $\mathrm{V}_{2} \mathrm{O}_{3}$ for pyrope-spessartine garnet has been mentioned previously only once, for material from East Africa (Koivula and Kammerling, 1988). Recently described samples from Sri Lanka (Johnson and Koivula, 1996a and b, 1998a) are even closer in color to the new blue-green material from Madagascar, but chemical analyses for these garnets have not been published.
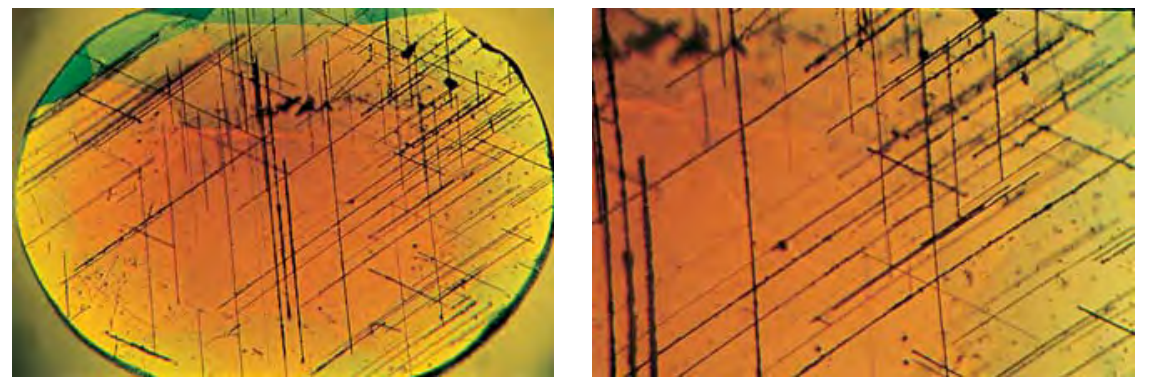

Figure 4. As seen with immersion at different magnifications in the same stone (30x, left; 50x, right), three sets of oriented rutile needles are visible in this blue-green color-change garnet from Bekily, in a view parallel to one of the [111] directions of the garnet. Each set is oriented at $70^{\circ}$ to an adjacent set. 

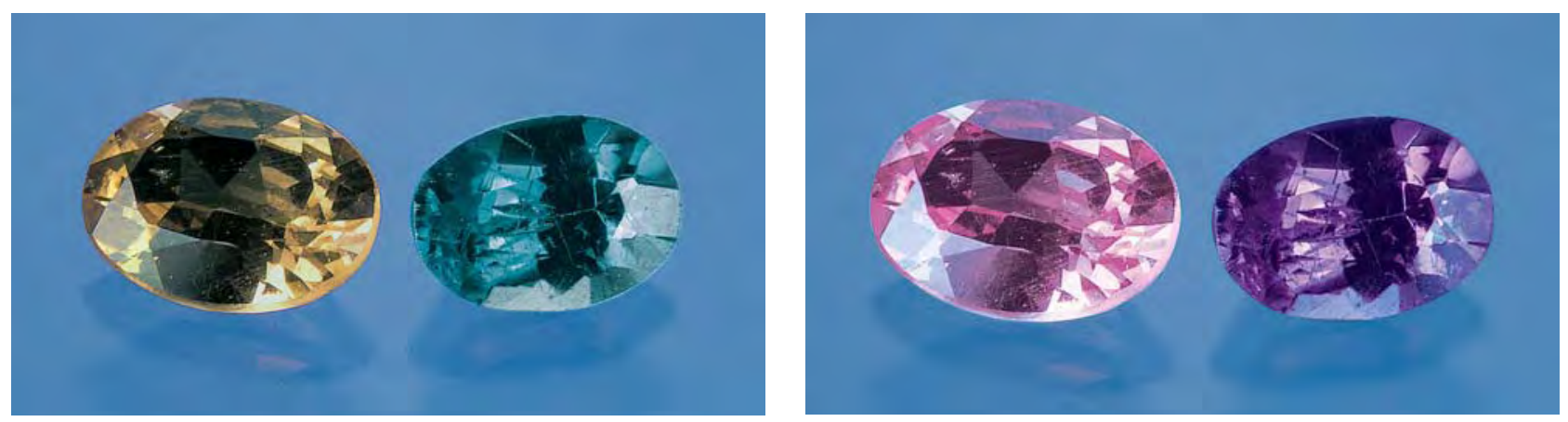

Figure 5. The two types of color-change garnets from Madagascar are shown here as they appear in day or fluorescent light (left) and incandescent light (right). The $0.35 \mathrm{ct}$ blue-green sample is rich in vanadium, with some chromium. The 0.44 ct greenish yellow sample has less vanadium and comparable amounts of chromium. Photo by Maha Tannous.

An unusual pyrope-spessartine with even higher contents of vanadium and chromium $(2.08 \mathrm{wt} . \%$ $\mathrm{V}_{2} \mathrm{O}_{3}, 1.05$ wt. \% $\mathrm{Cr}_{2} \mathrm{O}_{3}$ ), which came from Sri Lanka, was bluish green in daylight but did not show much of a color change (Schmetzer and Ottemann, 1979). The absorption maximum of its $\mathrm{V}^{3+}\left(\right.$ plus $\left.\mathrm{Cr}^{3+}\right)$ absorption band occurred in the yellowish orange region at $588 \mathrm{~nm}$. This value is below the small range $(562-578 \mathrm{~nm})$ within which an alexandritelike color change can be seen in gem materials.

\section{CONCLUSION}

Commercial quantities of a pyrope-spessartine garnet that is bluish green to greenish blue in daylight and purple in incandescent light have entered the gem market. We believe that these are the first commercially available (almost) blue garnets. The blue-green color is caused by unusually high amounts of vanadium. Microscopic examination revealed the presence of four sets of needle-like inclusions, with each set at an angle of $70^{\circ}$ to the others. Analysis of these inclusions in some of the samples showed that they were rutile. A greenish yellow color-change garnet, also from Madagascar, contained less pyrope and almandine, more spessartine, and distinctly more grossular. This material also revealed significantly less vanadium than the blue-green color-change garnets.

\section{REFERENCES}

Deer W.A., Howie R.A., Zussman J. (1992) An Introduction to the Rock-Forming Minerals, 2nd ed. Longman Scientific and Technical, Essex, England.

Fryer C., Ed. (1982) Gem Trade Lab notes: Rare inclusion in diamond. Gems «) Gemology, Vol. 18, No. 3, pp. 169-170.

Gübelin E., Schmetzer K. (1982) Gemstones with alexandrite effect. Gems \&) Gemology, Vol. 18, No. 4, pp. 197-203.

Johnson M.L., Koivula J.I., Eds. (1996a) Gem news: Color-change garnet. Gems «) Gemology, Vol. 32, No. 1, p. 53

Johnson M.L., Koivula J.I., Eds. (1996b) Gem news: A second Sri Lankan locality for color-change garnet. Gems \&) Gemology, Vol. 32, No. 4, pp. 285-286.

Johnson M.L., Koivula J.I., Eds. (1998a) Gem news: "Almost blue" Sri Lankan color-change garnets. Gems ef Gemology, Vol. 34, No. 2, pp. 138-140.

Johnson M.L., Koivula J.I., Eds. (1998b) Gem news: Color-change pyrope-spessartine garnet, also from Madagascar. Gems \&) Gemology, Vol. 34, No. 3, pp. 222-223.

Koivula J.I., Kammerling R.C., Eds. (1988) Gem news: Change-ofcolor garnets. Gems ↔ Gemology, Vol. 24, No. 3, pp. 176-177.

Liu Y., Shigley J.E., Fritsch E., Hemphill S. (1999) Colorimetric study of the alexandrite effect in gemstones. Journal of Gemmology, Vol. 26, No. 6, pp. 371-385.

Manson D.V., Stockton C.M. (1984) Pyrope-spessartine garnets with unusual color behavior. Gems Æ Gemology, Vol. 20, No. 4, pp. 200-207.

Mercier A., Moine B., Delorme J., Rakotondrazafy M.A.F. (1997) A note on a new occurrence of vanadian grossular garnet from Madagascar. Journal of Gemmology, Vol. 25, No. 6, pp. 391-393.

Schmetzer K., Bank H., Gübelin E. (1980) The alexandrite effect in minerals: Chrysoberyl, garnet, corundum, fluorite. Neues Jahrbuch für Mineralogie Abhandlungen, Vol. 138, No. 2, pp. 147-164.

Schmetzer K., Ottemann J. (1979) Kristallchemie und Farbe Vanadium-haltiger Granate. Neues Jahrbuch für Mineralogie Abhandlungen, Vol. 136, No. 2, pp. 146-168.

Stockton C.M. (1982) Two notable color-change garnets. Gems (4) Gemology, Vol. 18, No. 2, pp. 100-101.

Stockton C.M., Manson D.V. (1985) Editorial forum: Unusual color-change garnet. Gems \&) Gemology, Vol. 21, No. 2, pp. $116-117$. 